\title{
IMPLEMENTASI PERMAINAN MENANGKAP BOLA PADA KELENTURAN DAN KOORDINASI OTOT JARI DAN TANGAN ANAK USIA 2 - 3 TAHUN
}

\author{
Mahkamah Brantasari \\ PG PAUD, FKIP, Universitas Widya Gama Mahakam Samarinda \\ ( brantasari@gmail.com) \\ Andi Aslindah \\ PG PAUD, FKIP, Universitas Widya Gama Mahakam Samarinda \\ ( aslindah.andirezky@yahoo.com )
}

\begin{abstract}
Children aged 2-3 years is a child whose motor development is very rapid, so it is necessary to conduct activities to train children motor, motorik should be directed and trained in some activities that are implemented in the game to catch the ball so that flexibility and coordination of finger muscles and hands of children develop in thorough in accordance with the maturity of the child itself. This study was conducted on 3 children aged 2-3 years who have not been able to catch the ball well, so the practice of catching the ball that is divided into three sessions that is close to the ball with a distance of $60 \mathrm{~cm}$, the second using the technique five times catch the ball, but with the distance increased to $90 \mathrm{~cm}$, and the third catch the ball that adds up to ten times but with the same distance of $90 \mathrm{~cm}$ until the child can catch the ball well. The game research catches the ball executed with a 15 hour time for 15 days in the live researcher's environment. In the results of this case study seen the movement between flexibility and finger muscle coordination began to wake up. This ability is influenced by the practice of catching the ball that is often done so that the child's body position and hands become flexible to catch every ball thrown at him. This of course adds to the child's concentration power, thinking power, skills, confidence and happiness in children. The more often a child practicing catching the ball the better the attitude and posture that the child has.
\end{abstract}

Keywords: Children 2 - 3 Years, Catch the ball, Flexibility and Coordination of finger and hand muscles

\section{PENDAHULUAN}

Perkembangan

motorik

merupakan salah satu faktor yang

sangat penting dalam perkembangan

individu secara keseluruhan. Pada

dasarnya, perkembangan motorik ini

berkembang sejalan dengan

kematangan saraf dan otot anak.

Sehingga, setiap gerakan anak

sesederhana apapun, adalah merupakan hasil pola gabungan yang

menyeluruh dari berbagai bagian

dalam tubuh anak yang dikontrol

oleh otak.

Anak usia 2 - 3 tahun memiliki

pertumbuhan fisik dan

perkembangan motorik yang luar

biasa pesat, pertumbuhan dan

perkembangan tidak hanya terjadi

pada penampakan yang mana dapat 
dilihat dari berubahnya bentuk fisiknya tetapi juga dalam kemampuan dan kebisaan anak dalam melakukan suatu tindakan atau gerakan.

Perkembangan motorik anak yang berusia 2 - 3 tahun dengan pertumbuhan fisiknya akan semakin banyak melakukan kegiatan mengeksplorasi gerakan mulai dari berjalan, berlari, melompat, berjingkat, memanjat dan kegiatan motorik kasar lainnya. selain kemampuann yang dimiliki anak usia dini dalam mengeksplorasi apa yang sudah bisa anak lakukan, sangat perlu untuk melakukan stimulasi motorik kasar anak, yaitu dengan melatih dan menstimulasi kelenturan dan koordinasi otot jari dan tangan anak, dengan melakukan kegiatan memproyeksi objek yaitu menangkap bola.

Anak usia 2-3 tahun sering disebut juga sebagai masa awal anak-anak, di mana ketergantungan secara praktis sudah terlewati dan di gantikan dengan tumbuhnya kemandirian. Masa awal anak-anak ini merupakan masa puncak anak bermain dengan permainannya hingga usia selanjutnya menjelang masa masuk sekolah, perkembangan yang terjadi selama masa awal anak-anak biasanya seputar penguasaan dan pengendalian lingkungan di sekitarnya yang oleh para psikolog disebut sebagai masa penjelajah, yaitu dimana anak-anak ingin mengetahui keadaan lingkungannya, bagaimana mekanismenya, bagaimana perasaannya dan bagaimana dapat menjadi bagian lingkungan tersebut. Pada usia ini anak suka meniru pembicaraan dan tindakan orang lain, dan yang paling menonjol adalah kreativitas anak dalam bermain.

Motorik kasar adalah gerakan tubuh yang menggunakan otot-otot besar atau sebagian besar atau seluruh anggota tubuh yang dipengaruhi oleh kematangan anak itu sendiri. Dorong anak berlari, melompat, berdiri di atas satu kaki, memanjat, bermain bola, mengendarai sepeda roda tiga. Perkembangan motorik adalah perkembangan pengendalian gerakan jasmaniah melalui kegiatan pusat syaraf, urat syaraf, dan otot yang terkoordinasi (Hurlock, 1978). Motorik kasar merupakan 
gerakan fisik yang membutuhkan keseimbangan dan koordinasi antar anggota tubuh, dengan menggunakan otot-otot besar, sebagian atau seluruh anggota tubuh. Perkembangan motorik kasar adalah perkembangan gerakan tubuh yang menggunakan otot-otot besar atau sebagian besar atau seluruh anggota tubuh yang dipengaruhi oleh kematangan anak itu sendiri (Endah, 2008).

Hurlock (1978) menyatakan dari beberapa studi perkembangan motorik yang diamatinya, ada lima prinsip perkembangan motorik kasar. Adapun lima prinsip perkembangan motorik kasar yaitu :

a. Perkembangan motorik kasar bergantung pada kematangan otot dan syaraf. Perkembangan motorik sangat dipengaruhi oleh organ otak. Otak lah yang mengatur setiap gerakan yang dilakukan anak. Semakin matangnya perkembangan sistem syaraf otak yang mengatur otot, semakin baik kemampuan motorik anak. Hal ini juga didukung oleh kekuatan otot anak yang baik. b. Perkembangan yang berlangsung terus menerus. Perkembangan motorik berlangsung secara terus menerus sejak pembuahan. Urutan perkembangan cephalocaudal dapat dilihat pada masa awal bayi, pengendalian gerakan lebih banyak di daerah kepala. Saat perkembangan syaraf semakin baik, pengendalian gerakan dikendalikan oleh batang tubuh kemudian di daerah kaki. Perkembangan secara proximodistal dimulai dari gerakan sendi utama sampai gerakan bagian tubuh terpencil. Misal bayi menggunakan bahu dan siku dalam bergerak sebelum menggunakan pergelangan tangan dan jari tangan.

c. Perkembangan motorik memiliki pola yang dapat diramalkan. Perkembangan motorik dapat diramalkan ditunjukkan dengan bukti bahwa usia ketika anak mulai berjalan konsisten dengan laju perkembangan keseluruhannya. Misalnya, anak yang duduknya 
lebih awal akan berjalan lebih awal ketimbang anak yang duduknya terlambat.

d. Reflek primitif akan hilang dan digantikan dengan gerakan yang disadari. Reflek primitif ialah gerakan yang tidak disadari, berlangsung secara otomatis dan pada usia tertentu harus sudah hilang karena dapat menghambat gerakan yang disadari.

e. Urutan perkembangan pada anak sama tetapi kecepatannya berbeda Tahap perkembangan motorik setiap anak sama. Akan tetapi kondisi bawaan dan lingkungan mempengaruhi kecepatan perkembangannya.

Kelenturan tubuh berguna untuk menghindari bahaya cedera. Ini karena otot dan persendian tidak kaku. Artinya, latihan kelenturan merupakan gerakan-gerakan yang dapat melenturkan otot-otot juga persendian.Kelenturan tubuh merupakan syarat agar gerak tubuhlebih supel dan efisien.Kelenturan atau flexibility sering diartikan sebagai kemampuan seseorang untuk menggerakkan tubuh atau bagian-bagian dalam satu ruang gerak yang seluas-luas mungkin, tanpa mengalami cedera pada persendian dan otot sekitarnya persendian. Oleh karena kelenturan ini berpangkal pada luas gerak bagian tubuh di sekitar persendian tertentu, maka kebutuhan akan tarap kelenturan ini akan berbeda-beda pada tiap cabang olahraga. Contohnya kelenturan yang dibutuhkan untuk cabang senam akan lebih besar dibandingkan cabang renang. Dalam hal ini yang menjadi masalah utama sama, yaitu taraf mana yang baik atau buruk bagi suatu persendian untuk kegiatan olahraga tertentu. Berbagai study mengungkapkan bahwa anak wanita lebih baik tingkat kelenturannya dari pada anak laki-laki. Ada kekhawatiran orang awam bahwa weight trainingdapat menyebabkan kekakuan otot sehingga mengurangi kelenturan-kelenturan persendian. Kusunitz dan Keeney (1958) menyatakan bahwa weight training tidak akan mengurangi kelenturan persendian. Kekakuan otot tidak akan terjadi apabila dalam melakukan weight traininggerakan dilenturkan sepenuhnya sesuai dengan ruang gerak maksimum pada 
sendi yang bersangkutan.

Perkembangan kelenturan seseorang itu mulai usia kanak-kanak hingga dewasa.

Koordinasi berarti kemampuan melakukan gabungan atau gerak beberapaketerampilan. Koordinasi (coordination) adalah kemampuan seseorang untuk mengintegrasikan bermacam - macam gerakan yang berbeda kedalam pola gerakan secara efektif.

Koordinasi adalah suatu kemampuan biomotorik yang sangat kompleks (Harsono, 1988). Menurut Bompa (1994) koordinasi erat kaitannya dengan kecepatan, kekuatan, daya tahan, dan kelentukan. Oleh karena itu, bentuk latihan koordinasi harus dirancang dan disesuaikan dengan unsur-unsur kecepatan, kekuatan, daya tahan, dan kelentukan.

Koordinasi (coordination) merupakan salah satu elemen kondisi fisik yang relatif sulit didefenisikan secara tepat karena fungsinya sangat terkait dengan elemen-elemen kondisi fisik yang lain dan sangat ditentukan oleh kemampuan siswa (Syafruddin,2011:118-119).
Koordinasi adalah kemampuan untuk berulang kali mengeksekusi urutan gerakan lancar dan akurat. Ini mungkin melibatkan indra, kontraksi otot dan gerakan sendi (MacKenzie, B.,2008)

Koordinasi (coordination), adalah kemampuan seseorang mengintegrasikan bermacam-macam gerakan yang berbeda kedalam pola gerakan tunggal secara efektif. Misalnya dalam bermain tenis; seorang pemain akan kelihatan mempunyai koordinasi yang baik bila ia dapat bergerak kearah bola sambil mengayun raket, kemudian memukulnya dengan teknik yang benar (Sajoto, 1995: 9).

Jadi latihan koordinasi merupakan suatu aktivitas beberapa sistem tubuh dan pola pergerakan untuk membentuk gerakan individu dan keterampilan yang diperlukan untuk tujuan tertentu.

Menurut Aziz (2008:162) Komponen komponen dalam koodinasi adalah: (1) struktur gerakan, (2) irama gerakan, (3) kelancaran gerakan, (4) Hubungan gerakan, (5) ketepatan dan kekonstanan gerakan, (6) Tempo gerakan, (7) luasnya gerakan. 
Berbagai teknik menangkap bola memerlukan sikap tubuh yang tertentu pada dasarnya, posisi tubuh untuk menangkap harus memungkinkan agar bola datang langsung kearah penangkap, agar dicapai sikap menangkap yang benar-benar memungkinkan disamping itu, yang tidak kalah pentingnya adalah prinsip menyerap gaya yang dibawah bola agar impact dari bola dapat tersalur dan dipatahkan sebesar mungkin. Caranya ikuti bola dengan kedua lengan dan salurkan daya penahan sedikit demi sedikit terhadap bola. Menangkap bola merupakan salah satu teknik dasar yang sangat penting dan pertama-tama yang seharusnya perlu dikuasai oleh setiap permainan.

Kadang manusia tidak menyadari kapan dimulainya belajar melakukan kegiatan menangkap. Biasanya hal tersebut di lakukan secara reflek begitu saja jika ada sesuatu yang mungkin membahayakan pada diri, dan berusaha untuk menghindari. Sumantri (2005: 89) awal dari usaha menangkap yang dilakukan oleh anak kecil adalah berupa gerakan tangan untuk menghentikan suatu benda yang menggulir dilantai atau benda yang didekatnya. Kemampuan anak akan semakin bertambah jika anak sering mengulang-ulang kegiatan tersebut. Karena dengan mengulang akan terjadi sinkronisasi gerakan tangan dengan kecepatan benda yang akan ditangkapnya.

Perkembangan ini menjadikan anak mampu untuk menangkap. Kemampuan menggulir bola jauh lebih mudah daripada menangkap bola, maka dari itu menggulir menjadi dasar latihan. Dalam usaha menangkap benda yang dilambungkan, pada awalnya anak hanya menjulurkan tangan lurus kedepan dengan telapak tangan terbuka menghempas keatas. Kemampuan menyesuaikan posisi tubuh dan tangan dengan posisi di mana benda datang masih belum dimiliki. Karena itu usaha menangkap yang dilakukan biasanya gagal. Hal tersebut terjadi pada anak yang berusia 3 tahun.

Kemampuan menangkap berkembang sejalan dengan kemampuan anak untuk menaksir kecepatan dan jarak benda yang akan ditangkap serta ketepatan reaksi gerak tangannya. Hurlock (1978: 160) keterampilan menangkap jauh lebih sulit jika dibandingkan dengan 
ketrampilan melempar, maka dari itu ketrampilan anak dalam menangkap bola berkembang kemudian. Hanya ada sedikit anak yang dapat menangkap pada usia 4 tahunan, kebanyakan anak dapat melempar pada usia menjelang 6 tahun.Kemampuan menangkap pada anak sejalan dengan kemampuan anak untuk menaksir sebuah kecepatan suatu benda dan jarak benda yang akan ditangkap serta ketepatan reaksi gerak tangan yang dilakukan oleh anak. Anak akan semakin mampu untuk bergerak menyesuaiakan posisi tubuh dan tangannya sesuai dengan benda yang akan ditangkapnya, sehingga gerakan anak menjadi semakin efektif

atau lentur dan tidak mengalami kekakuan. Untuk memposisikan diri atau menyesuaikan dengan benda yang akan ditangkap anak melakuakan gerakan menekuk siku dan menarik siku ke samping badan.

\section{METODE PENELITIAN}

Secara umum, studi kasus merupakan strategi penulis dalam melakukan suatu penelitian berkenaan dengan pertanyaan bagaimana melakukan kegiatan yang berkaitan dengan menangkap bola yang diperuntukkan bagi anak yang berusia 2-3 tahun. Dengan jangka waktu yang tidak lama. Dan mengapa hal ini harus dilakukan, disini peneliti membuat desain penelitian atau rencana kerja, Desain penelitian adalah logika keterkaitan antara data yang harus dikumpulkan(dan

kesimpulan-kesimpulan yang akan dihasilkan) dan pertanyaan awal suatu penelitian. Sebagai definisi ringkas, dua penulis yaitu Nachmias dan Nachmais telah mendiskripsikan desain penelitian sebagai suatu rencana yang " membimbing peneliti dalam proses pengumpulan analisis dan interprestasi observasi. Ini merupakan suatu model pembuktian logis yang memungkinkan peneliti untuk mengambil inferensi mengenai hubungan kausal antar variabel didalam suatu penelitian. Desain penelitian tersebut juga menentukan ranah kemungkinan generalisasi, yaitu apakah interprestasi yang dicapai dapat digeneralisasikan terhadap suatu populasi yang lebih besar atau situasi-situasi yang berbeda. (Yin:2011,28). sebagai blue print penelitian yang berkenaan dengan 
pertanyaan yang harus diajukan adalah bagaimana implementasi permainan menangkap bola pada kelenturan dan koordinasi otot jari dan tangan pada anak usia 2-3 tahun dilaksanakan, dan bagaimana menganalisisnya.

\section{Penelitian dilaksanakan} dalam waktu yang tidak lama yaitu dalam waktu 15 jam selama 15 hari, dengan melatih anak usia 2-3 tahun sebanyak 3 orang anak yang ada di lingkungan peneliti. Penyelenggaraan penelitian, yang mencakup keterampilan keterampilan yang dituntut dari peneliti, latihan dan persiapan untuk studi kasus (persiapan pengumpulan data, pelaksanaan pengumpulan data) dan menganalisis bukti studi kasus tersebut.

Penelitian ini menggunakan metode kasus yang memiliki ciri-ciri yang dapat membedakannya dari strategi yang lain. Definisi yang diberikan oleh Yin (Yin, 2011:18) adalah sebagai berikut: "studi kasus adalah suatu inkuiri empiris yang (1) menyelidiki fenomena didalam konteks kehidupan nyata, (2) bilamana batas-batas antara fenomena dan konteks tampak dengan tegas dan (3) dimana multisumber bukti dimanfaatkan.

\section{HASIL PENELITIAN DAN PEMBAHASAN}

Kegiatan penelitian dilaksanakan di lingkungan tempat tinggal peneliti sendiri yang mengambil objek anak usia dini yang berumur 2 sampai 3 tahun yang berjumlah 3 orang anak. Setiap sore dengan waktu 1 jam selama lima belas hari anak-anak diajak bermain dengan menggunakan bola, kegiatan melempar bola dilakukan oleh peneliti yang dibantu oleh orang dewasa yang lain dan menangkap bola dilakukan oleh anak. Pada hari pertama hingga akhir kegiatan, peneliti membuat pijakan main bagi anak-anak dengan mengelola lingkungan main, merencanakan intensitas bermain, menyiapkan bahan atau peralatan bermain, yaitu berupa bola dengan ukuran diameternya $8 \mathrm{~cm}$.Dan menata kesempatan bermain menangkap bola agar tercipta suasana yang akrab dan tidak asing bagi anak. Selanjutnya anak-anak di beri pemahaman sesuai dengan bahasa anak dan contoh untuk menangkap bola dengan meletakkan kedua 
tangan sejajar dengan dada dan menghadap keatas, hingga hari ke tiga anak-anak belum bisa menangkap bola dengan baik, bola selalu terjatuh karena anak-anak jarang bahkan ada yang belum pernah menangkap bola. Hal ini terjadi dikarenakan tangan dan jari anak masih belum merespon gerakan bola, sehingga masih kaku, kelenturan dan koordinasi jari dan tangan belum tampak.

Pada hari kedua, peneliti membuat metode menangkap bola dengan cara membaginya menjadi tiga sesi menangkap bola. Yang pertama (dilaksanakan pada hari kedua hingga hari kelima) dengan lima kali menangkap bola dengan jarak dekat yaitu sekitar 60 senti meter, dengan jarak dekat ini anak awalnyapun tetap belum bisa menangkap bola, kegiatan melempar bola terus dilanjutkan dan di ulang hingga tiga kali itupun setelah lemparan 4 dan 5 anak mulai bisa menangkap bola yang dilemparkan kearahnya, dan kegiatan menangkap bola terus dilanjutkan hingga berjumlah menjadi 8 kali menangkap bola. Anak mulai berani dan banyak bergerak karena melihat dan mencontoh perilaku pelatih.
Sesi kedua yang dilaksanakan pada hari ke enam hingga kesembilan, dengan tetap menggunakan teknik lima kali menangkap bola, namun dengan jarak yang bertambah 90 sentimeter. Awalnya Anak mengalami kesulitan menangkap bola karena jarak yang semakin jauh dan anak dalam posisi yang tidak siap karena anak melakukan kegiatan sambil bermain, kegiatan menangkap bola dilanjutkan pada saat anak sudah siap untuk menangkap bola. Pada sesi kedua ini harapannya adalah dengan adanya pelatihan di awal terjadi perubahan gerak dan kemampuan anak. Kelenturan otot-otot tangan mulai tampak dilihat dari gerakan menangkap bola yang fleksibel dan tidak kaku (lebih luwes). Koordinasi otot jari dan tangan mulai terlihat dan tampak pada saat anak menangkap bola dan memegang bola agar tidak terjatuh.

Pada sesi ketiga yang dilaksanakan pada hari kesepuluh hingga hari keempat belas, anak terlihat sudah berani, sudah terdapat perubahan-perubahan gerakan, serta muncul kekuatan dan keseimbangan dalam mengendalikan tubuhnya, pada sesi yang ketiga dengan tekhnik 
menangkap bola yang jumlahnya bertambah hingga sepuluh kali tetapi dengan jarak yang sama yaitu 90 sentimeter.

Kegiatan menangkap ini dilakukan hingga sepuluh kali agar anak-anak terbiasa untuk menangkap bola yang di lemparkan kepadanya. Hari kelima belas kegiatan menangkap bola masih dilakukan dengan tujuan agar menangkap bola oleh anak menjadi lebih ajeg, anak sudah bisa menangkap bola dengan luwes walaupun masih ada bola yang terjatuh. Selama pelaksanaan kegiatan anak di berikan waktu untuk memperluas pengalaman menangkap bola sehingga anak memiliki waktu berinteraksi dengan anak yang lain, memahami cara menangkap bola dan mengingat kembali cara menangkap bola. Sehingga kelenturan tubuh anak dan koordinasi otot jari dan tangan terbentuk dalam melakukan gerakan dan membuat ruang gerak semakin luas dan semakin banyak gerakan yang di kuasai anak. Hal ini tentu saja menambah daya konsentrasi anak, daya pikir, rasa percaya diri dan kebahagiaan pada anak. Semakin sering anak berlatih menangkap bola maka semakin baik sikap dan postur tubuh yang dimiliki anak.

\section{PENUTUP}

\section{Kesimpulan}

Berdasarkan hasil penelitian yang telah dilaksanakan pada anak usia 2-3 tahun yang berjumlah 3 orang anak, kegiatan yang dilaksanakan selama 15 hari dengan melaksanakan kegiatan menangkap bola, anak yang semula belum bisa menangkap bola dengan bola yang sering jatuh, pada pelatihan yang kedua dan ketiga anak sudah bisa menangkap bola dengan lebih baik dengan jumlah tangkapan bola yang semakin banyak dan gerakan tubuh anak semakin luwes dan mulai banyak menguasai gerakan.Selama pelaksanaan kegiatan anak di berikan waktu untuk memperluas pengalaman menangkap bola sehingga anak memiliki waktu berinteraksi dengan anak yang lain, memahami cara menangkap bola dan mengingat kembali cara menangkap bola. Disini penulis merekomendasikan agar orang dewasa (orang tua atau guru) hendaklah rajin melakukan kegiatan menstimulasi motorik anak usia dini, Sehingga kelenturan tubuh anak, 
koordinasi otot jari dan tangan terbentuk dalam melakukan gerakan dan membuat ruang gerak semakin luas serta semakin banyak gerakan yang di kuasai anak. Hal ini tentu saja menambah daya konsentrasi anak, daya pikir, keterampilan, rasa percaya diri dan kebahagiaan pada anak. Semakin sering anak berlatih menangkap bola maka semakin baik sikap dan postur tubuh yang dimiliki anak.

\section{DAFTAR PUSTAKA}

Hurlock, Elizabeth. 1980. Suatu Pendekatan Sepanjang Rentang Kehidupan. Jakarta, Penerbit Erlangga.

Kosasih, Engkos. 1985. Olahraga Teknik dan Program Latihan. Jakarta : $\quad$ CV Akademika Pressindo

MacKenzie,B.2008.

Koordinasi, (online)(http://www.brianmac. co.uk/coord.htm. diakses 15 Februari 2012).

Sajoto. 1995. Peningkatan dan Pembinaan Kekuatan Kondisi Fisik dalam Olahraga. Dahara Prize: Semarang.

Singgih, D Gunarsah. 1996. Psikologi Olahraga. Jakarta : PT. BPK Gunung Mulia.
Syafruddin. 2011. Ilmu Kepelatihan Olahraga.Padang: UNP Press.

Yin Robert K. 2011. Studi Kasus Desain dan metode. Jakarta: PT Rajagrafindo Persada.

http://tiasulistiya.blogspot.co.id/201 5/06/latihan-koordinasi-mata-t angan-dan-kaki.html

http://informasitips.com/stimulasi-m otorik-kasar-anak-usia-2-3-tah un

http://walpaperhd99.blogspot.co.id/2 015/10/latihan-kelenturan-dan -koordinasi.html

http://nannesta.blogspot.co.id/2012/ 01/perbedaan-kelentura-denga n-kelentukan.htmlDiposting oleh nasrullah annesta di $\underline{01.44}$

https://manfaat.co.id/manfaat-latiha $\underline{\text { n-kelenturan-tubuh }}$

http://septalizadewi.blogspot.co.id/2 012/09/koordinasi.html

http://edhay76.blogspot.co.id/2015/1 0/teknik-menangkap-bola-pad a-bola-tangan.htmlPosted by Edi Sudrajat at 5:18 AM

http://eprints.uny.ac.id/13153/1/skri psi\%2010111244032.pdf 